\title{
Professional nursing identity: a perspective through the brazilian
} printed media lenses ${ }^{a}$

\author{
Identidade profissional de enfermagem: uma perspectiva através das lentes da mídia impressa brasileira \\ Identidad profesional de enfermería: una perspectiva a través de las lentes de medios impresa brasileña
}

Amina Regina Silva ${ }^{1}$ (])

Maria Itayra Padilha ${ }^{1}(\mathbb{D}$

Vânia Marli Schubert Backes ${ }^{1}$

Juliana Bonetti de Carvalho ${ }^{1}$ (1)

1. Universidade Federal de Santa Catarina.

Florianópolis, SC, Brasil.

\section{Abstract}

Objective: To analyze the historical events of the nursing profession presented by the Brazilian print media and that were configured as important in the (re/des) construction of the professional identity, from 1980 to 1986. Method: Qualitative research with a documental historical nature guided by historical investigation process, using 80 articles published in newspapers of great national circulation. Results: They portrayed the nursing struggles and representative entities to improve working conditions, the highlights for intercurrences in the nursing area, as well as the media portrayal of the stereotype of nursing at the time. Conclusion: The stereotypes traced by print media result in a double impact on nursing and its professional identity. On the one hand, it adds visibility to the struggles and gains of the category, and on the other, it generates devaluation by portraits of intercurrences in the exercise of the profession without pertinent contextualization and explanation of the facts that approached and resulted in such an event.

Keywords: Professional Practice; Nursing; Government Regulation; History of Nursing

\section{Resumo}

Objetivo: Analisar os acontecimentos históricos da profissão de enfermagem apresentados pela mídia impressa brasileira e que se configuraram como importantes na (re/des) construção da identidade profissional, no período de 1980 a 1986 . Método: Pesquisa qualitativa de cunho histórico documental, orientada pelo processo de investigação histórica, utilizando 80 reportagens publicadas em jornal de grande circulação nacional. Resultados: Retrataram as lutas da enfermagem e entidades representativas para melhoria das condições de trabalho, os destaques para intercorrências na área de enfermagem, e ainda o retrato da mídia sobre o estereótipo da enfermagem da época. Conclusão: Os estereótipos traçados pela mídia impressa resultam em um duplo impacto na enfermagem e sua identidade profissional. De um lado se agrega visibilidade para as lutas $e$ ganhos da categoria, e por outro gera desvalorização por retratos de intercorrências no exercício da profissão sem pertinente contextualização e explanação dos fatos que acercavam e resultavam em tal acontecimento.

Palavras-chave: Prática Profissional; Enfermagem; Regulamentação Governamental; História da Enfermagem.

\section{Resumen}

Objetivo: Analizar los acontecimientos históricos de la profesión de enfermería presentados por los medios impresos brasileños y que se configuraron como importantes en la (re/des) construcción de la identidad profesional, en el período de 1980 a 1986 Método: Investigación cualitativa de cuño histórico documental, orientada por proceso de investigación histórica, utilizando 80 reportajes publicados en periódico de gran circulación nacional. Resultados: Retractaron las luchas de la enfermería y entidades representativas para mejorar las condiciones de trabajo, los destaques para intercurrencias en el área de enfermería, y el retrato de los medios sobre el estereotipo de la enfermería de la época. Conclusión: Los estereotipos trazados por los medios impresos resultan en un doble impacto en la enfermería y su identidad profesional. De un lado se agrega visibilidad para las luchas y ganancias de la categoría, y por otro genera desvalorización por retratos de intercurrencias en el ejercicio de la profesión sin pertinente contextualización y explicación de los hechos que acercaban y resultaban en tal acontecimiento.

Palabras clave: Práctica Profesional; Enfermería; Regulacíon Gubernamental; Historia de la Enfermería.
Corresponding author:

Amina Regina Silva.

E-mail: aminareginasilva@gmail.com

Submitted on $06 / 15 / 2018$

Accepted on $08 / 15 / 2018$.

DOI: 10.1590/2177-9465-EAN-2018-0182 


\section{INTRODUCTION}

The present study has as an object the image of nursing linked in the printed media in national scenery, related to the process of professional identity experienced. This artifice is linked to the influence of past epochs for the construction, deconstruction and reconstruction of the nursing professional identity according to the individual's experiences. ${ }^{1}$

Nursing's professional identity is a thematic that have been studied for decates in diverse areas. In this study, we focused on concepts from sociology about identity, more specifically from the french sociologist Claude Dubar. This author highlights the importance of socialization processes in the formation of a professional identity, and it's based on these processes and in characteristics that differ us from others in a group of people, that we manage to define who we are professionally, the so called professional identity. ${ }^{2}$

In the nursing area, the process of identity has diverse influences included in the profession's context, among movements and nursing actions. Being still in what concerns the media, there is a highlight for negative factors of the profession. As an exemple, from daily nursing actions, when it generates adverse events as results from a series of situations and errors of diverse related areas. ${ }^{3}$

Nursing is considered by researchers as the top of the iceberg, because even though the adverse event is a result from innumerous factors from different areas that converge to allow it's occurance, the one who executes and concretizes such facts are nursing professionals due to care provided directly to patients. Thereby, in the occurrence of these events, the negative highlight turns to nursing with such intensity that makes it difficult for people who are not included in this everyday to understand the situation as a consequence of a confluence of actions, not the exclusive act of a single profession. ${ }^{3}$

This perspective may still itensify in a negative way around nursing, this, obtained as a result when the media focuses on health issues in general, the contents reported are more prominent, when associated with critical health factors. In this context, it's important to highlight here that there is a relationship between consumption and selling printed media, in which the consumer investment is not enough to subside all activities from the mediatic sector, hence, it is required the use of 'extra sourcers', such as publicity activities to raise sector's revenue, that's why the higher the newspapers sell, the greater focus in such investors. When there are impacting factors in news, this news are more salable, because it's a highlight for the consumer, fact that boost editors and journalists of the publication of critical factors in the health area. ${ }^{4}$

When you work with printed media, it's valid to remember that at the same time it highlights factors and points of view that denigrate the image of nursing, it's also capable to promote such image, highlighting fights and movements of category in search of improvements of work conditions. In this context, we highlight law no 7.498 from 1986, that regulates the professional practice, which was a result from a group of working fights and representitive entities in search of a better condition to the category of nursing. ${ }^{5}$

Thus, when you reflect about this aspects, the following questions raise: how were the events in nursing practice? How does the media reported this aspects before regulation's update? Does this fact justify the choice of time frame of this study which comprehended six years before the publication of the law $\mathrm{n} \times \mathbf{0} .498$ from June $25^{\text {th }} 1986$, which regulates the practice of Nursing and provides other measures. The intention to precede the temporal cut in six years prior to the 7,498 legislation is to understand the factors, struggles and historical processes may have implied in the emergence and approval of this new professional legislation.

From the foregoing, this study aims to analyze the historical events of the nursing profession presented by the Brazilian print media and which were configured as important in the (re/de) construction of professional identity, from 1980 to 1986.

\section{METHOD}

This study is a historic qualitative research, with the use of printed newspapers as source from documental research, which was classified as primary source in this context, because it served as basis to give origin to another scientifical domain knowledge.

This research used as primary source the newspaper " $A$ Folha de São Paulo" from São Paulo, which is considered by many researchers one of the main vehicles of information from printed media. ${ }^{6,7}$ To collect data we used the online archive from the newspaper "A Folha", considering that this has all period to be studied available in its archive. We sought all news published between the timeframe 1980 to 1986, that contemplate, in its context, keywords nurse and/or nursing. In the research's initial step there was an access to 2.944 news which, during the data analysis step were read individually fully.

According to thematic adherence, news were selected and saved in individual documents and still, concomitantly, data collection table was filled, which was developed specifically for this study. From the initial total of news, after data collection steps, 2.863 news were excluded, resulting in a final sample that composed the research, which were 81 news. The motive which resulted in the exclusion of these 2.863 news were: lack of thematic adherence, treating only of nurse's social identity and not professional, that is, to approach individuals and one's role in society, but without a correlation with one's professional role; low relevance for the research and low thematic explanation, bringing thus insuficient content to subside a discussion with quality.

According to norms and guidelines proposed by the Research Involving Human Beings Ethics Committe (CEPSH), defined in the resolution $n^{\circ} 466$, from December $12^{\text {th }} 2012$, from National Health Council, it's a research of documental approach and that employs public documents of free access 
to the population, dispensing the need to previous submit the article to CEPSH. There's also the resolution $\mathrm{n}^{\circ} \mathbf{5 1 0}$ from April $07^{\text {th }} 2016$ that cites that will not be registered and evaluated by the CEP/CONEP system, researches that use public information in terms of the law no 12.527/2011 and researches that use information of public domain. ${ }^{8}$

\section{RESULTS}

In this initial step results were exposed according to two categories that fomented this manuscript, they are: nursing events in the media; nursing portrait in television/books.

\section{Nursing events in the media}

This first category was composed by 71 news and it was formed by only one section, denominated 'Polemic issues', and they were different polemics in the area of nursing. Which, at times, related to adverse events, inappropriated conducts and for other related to protests such as strikes, function desviation, overload, among others. Among findings in this category, it's possible to verify different groups of news. 33 news that were about protests and strikes from nursing category were found, being that most of it had as foundation bad work conditions for nursing, people incorrect dimensioning, beyond diverse unjust layoffs to cut costs, layoffs of old workers or substitution of workers inside a nursing category. In order to better exemplify these findings, here are the more impacting news.

\section{News 1 - "São Paulo Hospital drags it's crisis waiting on MEC" - Data:13/04/1980 - Pg. 22.}

"Even though the layoff and evation of most of workers, hospital's superintendent doesn't intend to hire anyone and all sectors of attendance are overloaded and don't receive the needed care, most of the time. In the cardiology unit, there is only one nursing assistant, in the night shift, to care for 29 patients, without couting the ones admitted to Intensive Care Unit, when it would also be necessary the presence of a qualified nurse. That's why there are frequent problems. There are days since a ptient had a cardiac arrest in Cardiology and didn't die because he was rescued in time.". 9

\section{News 2 - "Workers ask for a better treatment" - Data: 01/06/1982 - Pg. 17}

"Workers from the Nursing division o Heart Institute from Clinical Hospital against "maltreatment that we are receiving from great part of chief nurses. We, workers, are very revolted with the language used with their subordinates. After telling some cases, they ask "provisions so that we are treated as human beings and not ragged or machines, without due feeling and even without due respect", because they state, they suffer repressions for only asnwering a communication "with or withour reason". We want to know where is the ethics preconized in this hospital?"s

Another finding was the 14 news that talked about nursing faults, happenings that weren't related in a direct way to nursing care, but were judged as inapproprieted. Beyond that, seve news brought up facts that can be considered important to patient safety, following some exemples.

\section{News 3 - "Hospital admits there were mistakes" - Date: 01/09/1980 - Pg. 11.}

"The manager from the Hospital São Bento, from Lapa, Antonio Carlos Mitne, responsabilized, yesterday, a nurse of the entity for the fact they provided a death attestation of an admitted child that have not died. On December $18^{\text {th }}$ 1979, the driver Francisco Honorato de Freitas admitted his daughter, Lilian Nunes de Freitas, at 10 months of age, in the São Bent hospital, São Gualter avenue, 218. On the 24 he was looked for policemen that informed the death of his daughter. Going to the hospital, the resident of $2 B$ Estevão Fernandes street, Piraporinha, Santo Amaro, received the needed documents to register death. It was only after he had arranged for the burial and returned to the hospital that he discovered the mistake, that his daughter was alive and well and that a boy named Luciano died".

\section{News 4 - "Resusable disposables in Rio Claro" - Date: 07/08/981 - Pg. 47.}

"The health center from the city Rio Claro, reuses disposable material, going against legal norms, according to report presented yesterday by the student Sebastião Machado P. Martins. The student said that he went to the health center to be vaccined and the nurse got an used needle from a container where there were other needles imersed in alcohol. He denied to be vaccined with an used needle, the student received the following information: "I know it's not permitted by law, but due the lack of money am authorized to used the disposible material 2 or 3 times, but if you want a new needle you will be able to buy it. ".

Concerning the adverse events, 18 reports were obtained, which had great impact in the media. These reports mostly dealt with serious events, which brought serious health consequences for the assisted patient, such as deaths, limb amputation and permanent sequelae. Further highlighting that of these events, (6) evolved to judicial judgment, some examples are mentioned. 


\section{News 5 - "Nurse's mistake makes boy's leg to be amputated" - Date: 12/11/1980 - Pg. 24.}

"BRAGANÇA PAULISTA (from correspondent) - The boy Jeferson Messias Guedes, of 3 years old, had a leg amputated yesterday, due to issed raised with the application of a benzotal injection in the croatch, instead of butt, it reached the femural artery and paralized the minor's leg ". ${ }^{9}$

\section{News 6 - "Nurse accused of mistake attempts suicide" - Date: 08/07/1985 - Pg. 19.}

"With ten years of experience of treatment of high risk sick people, Neuci applied in Deolinda's vein, instead of serum, an aluminum hydroxide compound that should have be inserted in the nasal-gastric catheter. Deolinda died almost instantly and right after, the nursing assistant tried to jump from the six floor from the hospital Neuci was amitted in a psychiatric clinic by family members, because she couldn't control her nerves after seeing the error she's done". 9

Also in this context, six reports reported crimes committed by nursing professionals during the exercise of the profession, among which, for the most part, they referred to physical and sexual violence, some examples.

\section{News 7 - "Ambulance" - Date: 12/14/1980 - Pg. 64.}

"They remained alone, inside the vehicle, the girl unconscious and the nurse. It was to him that he could not resist the urge of sex. He lifted the white sheets, which covered the girl's plump, dark forms, and raped her there, lying on the stretcher in the middle of an ambulance. The girl realized the violence she was being victimized. She opened her lips and her eyes. But torpor kept her from reacting. She was aware of everything, though. Satisfied, the nurse left the unhappy woman. A few minutes later, he answered hers aunt as if nothing had happened.".9

\section{News 8 - "Hospital is accused to beat pantient up" - Data: 01/02/1984 - Pg. 10.}

"Reinaldo Satô's family, a mental patient admitted since December $8^{\text {th }}$ in the Instituto Modelo de Itaquaquecetuba, is accusing a hospital worker of having beating him up. According the family, in visitation day, last thrusday, Reinaldo complained of strong abdominal pain. Another patient, Arlindo Cândido da Silva, who was discharged in recent days, said he saw nursing attendant Gérson Pilate assault Reinaldo and two other patients". ${ }^{9}$

\section{Nursing portrait in television/books}

This second category has brought to the forefront factors related to the nurses' portrayed image on television and books, based on reports from the print media. For the formation of this category there were two distinct sections, the first on films that contained in their cast some actor who played the role of nursing professional in the dramaturgy, and the second on books, that had in their cast some actor who played the role of nursing professional or work of the nursing area.

In the film plot, we had the eight featured articles, five dealing with a novel that involved a nurse as part of the main couple, two with roles related to professional nursing practice, and one involving a killer nurse. When the reports were repeated, they were counted only once, since there was an incidence of the same publication up to 37 times in that category. As examples of this category was the film "Love in Flames" under the direction of Hanover Street in 1979, which dealt with a romantic drama involving three parts, a nurse, her husband and her husband's friend. And another example to be highlighted was the film "The Indoctrination of Vera" about a nursing assistant and her process of indoctrination.

With regard to the nursing image reported in the books, we had two reports that presented in full the professional nursing practice. Being one considered a scientific book and another the story of a devoted nurse in the struggle for improvements of her profession.

These news, in general brought an image projected by the printed media, speicifically, coming from the newspaper " $A$ Folha", in relation to nursing professional. This enabled to project a possible vision of brazilian society at the time, when they based their conception on the media printed, and how these aspects and views impacted in the process of professional nursing identity, which will be discussed in the following.

\section{DISCUSSION}

Nursing's image in the printed media implicates in the comprehension of diverse contexts, initiating in the bias already presented refered to mediatic aspects, which comprehends in creating an image projected by a group of people. The media uses an artifice that has pecularities and singularities referred to the way of development in news, having in consideration that the media disposes of their own rules in the process of creating news. ${ }^{10}$

Taking a retrospective of the 1980s, it is possible to visualize acquisitions for Brazilian nursing in the national scenario, highlighting the approval of Law No. 7.498/86 that regulates the professional nursing practice and brings the need for the Systematization of Nursing Assistance. This imposes the need of nurses in all health institutions where the nursing team works, in addition to subsequently being considered as a highlight for the autonomy and evolution of nursing as a profession. ${ }^{11,12}$ 
As for the issue of the demands of the nursing category, strikes and protests have first been highlighted, through mobilizations of this category in the fight for the conquest of their rights and for the improvement of working conditions, which has impacted on the profile and professional identity of the time in a direct way. It is important to emphasize the professional devaluation and poor working conditions as a factor that stimulated these category movements, linked to the lack of distinction of the nursing categories and their functions, which sometimes generated undue substitutions and dismissals among the nursing category. Working conditions can be defined as a set of characteristics involved in the work activities present in the daily work, and it still associated with interpersonal relationships.

Hospitals are considered places of risk to the health of the worker, this also in association with the risks of exposure to psycho-biological factors, which makes it even more difficult to be present in such environments. These aspects also influence the psychic health of health workers, this in an inversely proportional relation, the more unfavorable the working conditions, the lower the psychic health of the worker. ${ }^{13}$

Another important factor that had a high incidence in all categories and sections of this manuscript was the lack of distinction of the nursing categories. In the reports researched, all professionals of the nursing team were considered as nurses, without clearly identifying the professional distinction. This was due to the lack of knowledge about the difference between nurses, technicians and nursing assistants. Also emphasizing that the nursing image in the media was associated with servility to the other health professions.

One aspect that Menegon ${ }^{14}$ emphasizes is the description of the media in front of the health area, since it follows the hegemony of the hospital-centered model, in which the hospital is highlighted in the daily life of the print media as the relevant part of health care. The author, in her research using printed media sources methodology, emphasizes that health issues are more frequently reported when referring to emergencies and hospital complexities, a fact also affirmed by Fontana, ${ }^{4}$ who also used print media as a documentary source in her work search.

When it comes to these errors involved in health care, specifically those involving the nursing team, it is important to point out the inadequate working conditions cited here that cause impacts on mental health, in addition to the low remuneration that sometimes generates double daily shifts influencing the physical and psychological exhaustion of professionals. The media often presents the failures and errors resulting from the care, such as iatrogeny and adverse events, in order to alert the population, but do not state the reasons that led to this event, or the conditions in which these professional was inserted. ${ }^{4}$

Another aspect to be pointed out regarding these events is that the temporal cut of this research was used a period prior to updating the regulation of professional nursing practice. Due to this, in that period, nursing was regulated by Law No.2,604, dated
September 17, 1955, where previously there were six categories of nursing: nurse, nursing assistant, obstetrician, midwife, practical midwife, practical nurse. ${ }^{12,16}$ Some of these categories did not have a well defined training and since there was no specific nursing council at the time, this could contribute to the existence of professionals without adequate qualification for the exercise of the profession. Since the creation of Law no. 4998/86, the categories have been reduced to four: nurses, nursing technicians, nursing assistants and midwives, emphasizing that in order to exercise their function each one must have the appropriate degree and registration in the Nursing Council. ${ }^{5}$

It can be understood that errors are not only results from a professional category. In order to allow the realization of an error, a series of errors by different professionals is required, as published by the Brazilian Institute for Patient Safety, ${ }^{17}$ in view of the "Swiss Cheese" theory. ${ }^{18}$ This theory compares the adverse event with a Swiss cheese, with several slices of Swiss cheese scattered side by side. In some situations, the slices align so that the holes coincide and align, as an outcome, allowing the event to pass through the multiple barriers, resulting in damage to the patient. ${ }^{18} \mathrm{It}$ should be noted that in the period of this study, there were few references to patient safety, making it difficult to understand and formulate policies to reduce adverse events. This is a theme of the present day that has been highlighted with the creation of the World Alliance for Patient Safety by the World Health Organization in 2004. ${ }^{19}$

Another aspect that was much addressed by the media in the scenario studied was hospital infection, which can be defined as infection from the health care process, which occurs during and after hospital admission. Hospital infection can be due to a series of means, be it from the patient, from his visits, or the most mentioned, from the health professionals. ${ }^{20}$ In the period of time studied, the number of mentions about the hospital infection process was significant. It is notable that there was an increase in the incidence of these reports after the death of the president of Brazil, Tancredo de Almeida Neves. He was considered the first civilian president elected after the dictatorship in 1985, and fell ill severely on the day of his inauguration. He died on April 21, 1985 , as a result of a generalized infection. It is inevitable to relate the incidence of these aspects to the approval of Law 9431, in 1997, which makes the existence of the Hospital Infection Control Commission $(\mathrm{CClH})$ and the Hospital Infection Control Program $(\mathrm{PClH})$ mandatory, in order to prevent and to reduce the incidence of infections in the hospital context. ${ }^{21}$

It is also important to highlight the lack of assistance to the professional involved in the events, such as report no 8 of this study, titled "Nurse accused of mistake attempts suicide". In addition to the implications arising from the error in the patient's health, there are also consequences for the worker, who experience feelings of fear, incapacity, impotence, concern and responsibility for the error and, for many times, receive no assistance from the institution. ${ }^{22} \mathrm{It}$ is important to understand that 
health professionals are human beings and that as humans are fallible, so errors and adverse events are expected even from the best health teams. ${ }^{23}$

We highlight the study ${ }^{3}$ on the disclosure of medication errors in the Brazilian media. The highest incidence of errors found by the authors was related to the dose, route or substance and also, among the consequences, that some professionals got to commit suicide by the lack of assistance. The mistakes exposed in the media, for the most part, were considered to be extremely serious, results that are in agreement with the findings of this research. In addition, another highlight was to the posterror moment, where the emphasis is given to punishment, rather than education to the professional.

Related to crimes committed by nursing professionals on practice such as physical or sexual violence, there are few scientific articles on the topic. It's important to comprehend that nursing must be oriented based on ethical concepts during the profession practice, respecting the individual as a human being from one's conception to death, independently on it's mental or psychic state. The patient should have their autonomy safeguarded and have freedom of expression to decide all stages of their treatment, being prohibited to the professional of nursing to provoke any form of violence to the patient, being able to answer judicially depending on the level of the violence..$^{24,25}$

In terms of the events and failures of nursing in the media, we have the study, in which the participants of the research report that the media presents a negative stereotype of nursing..$^{15}$ According to the authors, this factor influences the devaluation of the profession and loss of credibility, resulting in unjust accusations on the part of patients in a generalized way to professionals. In addition to bringing nursing in general in the vision of a beautiful and sexy woman, without scientific depth and submissive to the medical professional, a degrading image in the view of the study participants.

Literatures and the media present aspects that negatively influence the patient/nurse relationship, due to the creation and strengthening of prejudices, distorting the image and function of the nurse as a professional member of the health team. This image shows a binarism involved in the media, and sometimes the nurse is seen as a white, charitable and Christian angel, and by others she is seen as a profane being. ${ }^{26}$

In the study of Lage and Alves ${ }^{27}$ it was evidenced that the actions of the society collective established by stereotypes and prejudices influence in an impactful way the exercise of nursing in daily life. For the authors, the nursing practice is often stimulated by professional recognition, and when there is no due recognition, the professional feels discouraged, not going beyond his obligations in the daily work. They point out that this lack of recognition does not come only from society, but also from the health team, which in general damages the nursing professional identity, since they generate the commitment in the construction of links.
In Porto and Neto's study ${ }^{28}$ that portraits the nurse in the Brazilian illustrated press, there is the need to work with the image created by the press, with the intent to improve the negative effect on professional identity from nursing's mediatic image. This can still be corroborated with facts found in ideas from Dubar,where there is the identity profile as a result in processes that alter, modify and reconstruct with the passing of time, enabling to be influenced by intrinsic factors related to individuals involved in such process. ${ }^{2}$

"Through nursing study and its history we can comprehend the fight started against stigmas and prejudices imposed by social ignorance reinforced by the media and the importance of acceptance and recognition of this profession by society". ${ }^{26}$

Based on concepts from these and other studies there is the comprehension that the image reported by the printed media, by many times, denigrate the nursing category. This is based on stereotypes and prejudices linked to a time past in nursing history, considered "nursing critical period". This was caused by the evasion of women religious from health care during the Protestant period, leaving people of low value in society, such as illiterates, prostitutes and street dwellers, to take "care". Even though this process did not occur concomitantly in Brazil, the prejudice crossed the frontiers by 'caravels' and had a concise impact on Brazilian nursing. In this view, it is necessary to understand the concepts present in the media and in the population in general, as this is the first step towards confronting and demystifying the profession, in order to reverse this situation and bring value to the nursing service, directly influencing the professional identity of nursing. ${ }^{26,29}$

It is highlighted as limitations of this study, a feature of the print media, which are its reports presenting short explanation and vision coming from ideas, often individual. Another fact was the lack of studies to discuss some findings of the research, which made it difficult to explain results, but on the other hand added value in this manuscript presenting unpublished aspects.

\section{CONCLUSIONS AND IMPLICATIONS FOR PRACTICE}

This text allowed to visualize the characteristics of the print media in relation to the nursing image portrayed in times of historical importance of the profession. This image portrays the struggles and battles of nursing to gain space and recognition as a profession, seeking their rights and improvements in working conditions, which were even worse in the period portrayed, because it anticipated the updating of professional nursing regulation.

It was also possible to understand the stereotypes portrayed by the print media in the national scene, giving great visibility to serious nursing errors in the exercise of the profession, which entails loss of credibility by the population and other professionals of the health team. This is accomplished by the fact that the media reports only the image of the nurse as being exclusively responsible, without considering the range of errors 
involved in the final design of an adverse event. In addition, it was possible, through some headlines, to perceive the lack of support provided to the professionals involved in the adverse event, resulting in psychic suffering and suicidal ideation.

The image in the media is strengthened through representations from films and books that insist on portraying nursing based on a historical binarism, on one side seen as angelic and Christian, which bases its professional practice on charity and, on the other hand, the profane image, coming from a sexy and beautiful nurse, with no scientificity involved in caring.

These aspects implied in a devaluation of nursing as a profession, which exercises its work with scientific care whether in the area of care or research itself. This devaluation impairs the professional identity of nursing and professional practice, since nursing has as one of its bases of incentive to the valorization of its work. When this does not occur, it causes the professionals to act in order to exercise only what is required of them, not going beyond their daily work, even if they have the capacity to do so.

It is necessary to understand the historical contexts that influence the devaluation of nursing as a profession by the print media, and its resulting impact in the eyes of society, to combat prejudices and stereotypes. Thus strengthening the image and professional identity of nursing as a profession, of a scientific nature, serious and not submissive to other professionals in the health area, possessing autonomy for the exercise of the profession and its ethical and legal precepts involved.

Finally, it is emphasized that the profession is exercised by human beings, who are capable of errors and failures, as in any other field. These failures should not be condemned, but should be understood and strengthened so that they do not recur.

\section{REFERENCES}

1. Bellaguarda MLR, Silveira LR, Mesquita MPL, Ramos FRS. Identidade da profissional enfermeira caracterizada numa revisão integrativa. Enferm Foco [Internet]. 2011; [cited 2016 May 27];2(3):180-3. Available from: http://revista.cofen.gov.br/index.php/enfermagem/article/view/130

2. Dubar C. A socialização: construção das identidades sociais e profissionais. São Paulo: Martins Fontes; 2005.

3. Volpe CRG, Aguiar LB, Pinho DLM, Stival MM, Funghetto SS, Lima LR Erros de medicação divulgados na mídia: estratégias de gestão do risco. Rahis [Internet]. 2016; [cited 2017 Jun 18]; 13(2):97-110. Available from http://revistas.face.ufmg.br/index.php/rahis/article/view/97-111. DOI: http://dx.doi.org/10.21450/rahis.v13i2.3499

4. Fontana RT, Wolf J, Rodrigues FCP, Castro LM. Análise documental da mídia escrita sobre eventos adversos ocorridos na prática da enfermagem. Rev Enferm UFPE On Line (Recife) [Internet]. 2015 May; [cited 2017 Jun 18]; 9(Supl. 4):8103-10. Available from: https:// periodicos.ufpe.br/revistas/revistaenfermagem/article/view/10565

5. Brasil. Lei №. 7.498, de 25 de junho de 1986. Dispõe sobre a regulamentação do exercício da Enfermagem e dá outras providências. Brasília (DF): Diário Oficial da União; 1986. Available from: http://www. planalto.gov.br/ccivil_03/leis//7498.htm

6. Jesus DSV. O Brasil no BRICS, segundo a Folha de S. Paulo e O Globo (2011-2013). Aurora Rev Art Míd Polt [Internet]. 2014 Sep; [cited 2017 Jun 18];20(7):51-81. Available from: https://revistas.pucsp.br/index.php/ aurora/article/download/20053/15411
7. Morais I, Alkmin D, Lopes J, Santos M, Leonel M, Santos R, et al. Jornais Folha de São Paulo e Correio Braziliense: o que dizem sobre o programa mais médicos? Rev Esc Enferm USP [Internet]. 2014; [cited 2017 Jun 18]; 48(Esp2):112-20. Available from: http://www.periodicos.usp.br/ reeusp/article/view/103115/101452. DOI: http://dx.doi.org/10.1590/ S0080-623420140000800017

8. Lucena DN, Ferreira KLC, Araujo RM, Pinheiro GG. Lei de acesso a informação: uma leitura da implementação do Instituto Federal do Rio Grande do Norte. Rev Pensam Realid [Internet]. 2014; [cited 2018 Jun 18]; 29(1):98-120. Available from: https://revistas.pucsp.br/index.php/ pensamentorealidade/article/view/17677/14534

9. Folha de São Paulo [Internet]. Acervo folha [cited 2017 Aug 20]. Available from: http://acervo.folha.com.br

10. Cavaca AG, Vasconcellos-Silva PR, Ferreira P, Nunes JA Entre evidências e negligências: cobertura e invisibilidade de temas de saúde na mídia impressa portuguesa. Ciênc Saúde Coletiva [Internet]. 2015 Nov; [cited 2017 Jun 3]; 20(11):356980. Available from: http://www.scielo.br/scielo.php?script=sci arttext\&pid=S1413-81232015001103569\&lng=pt\&tlng=pt. DOI: http:// dx.doi.org/10.1590/1413-812320152011.18342014

11. Lorenzetti J, Pires DEP, Spricigo J, Schoeller SD. Unidade de ação: um desafio para a enfermagem brasileira. Enferm Foco [Internet]. 2012 [cited 2017 Jun 18]; 3(3):152-4. Available from: http://revista.cofen.gov. br/index.php/enfermagem/article/viewFile/304/164

12. Kletemberg DF, Siqueira MTD, Mantovani MF, Padilha MI, Amante LN Anders JC. O processo de enfermagem e a lei do exercício profissional. Rev Bras Enferm [Internet]. 2010 Jan/Feb; [cited 2017 Jun 18] 63(1):26-32. Available from: http://www.scielo.br/scielo.php?script=sci_ arttext\&pid=S0034-71672010000100005\&lng=en\&nrm=iso

13. Costa MTP, Borges LO, Barros SC. Condições de trabalho e saúde psíquica: um estudo em dois hospitais universitários. Rev Psicol Organ Trab [Internet]. 2015 Jan/Mar; [cited 2017 Jun 23]; 15(1):43-58. Available from: http://pepsic.bvsalud.org/pdf/rpot/v15n1/v15n1a05.pdf.DOI:http:// dx.doi.org/10.17652/rpot/2015.1.490

14. Menegon VSM. Crise dos serviços de saúde no cotidiano da mídia impressa. Psicol Soc [Internet]. 2008; [cited 2017 Jun 3]; 20(no. spe):32-40. Available from: http://www.scielo.br/scielo.php?script=sci arttext\&pid=S0102-71822008000400006\&lng=pt\&tlng=pt. DOI: http:// dx.doi.org/10.1590/S0102-71822008000400006

15. Avila LI, Silveira RS, Lunardi VL, Fernandes GFM, Mancia JR, Silveira JT. Implicações da visibilidade da enfermagem no exercício profissional Rev Gaúcha Enferm [Internet]. 2013 Sep; [cited 2017 Jun 18]; 34(3):1029. Available from: http://www.scielo.br/scielo.php?script=sci_arttext\&pi $\mathrm{d}=$ S1983-14472013000300013

16. Ribeiro G, Pires DEP, Flor RC. Concepção de biossegurança de docentes do ensino técnico de enfermagem em um estado do sul do Brasil. Trab Educ Saúde [Internet]. 2015;13(3):721-37. Available from: http://www. scielo.br/scielo.php?pid=S1981-77462015000300721\&script=sci_ abstract\&tlng=pt

17. Forte ECN, Pires DEP, Martins MMFPS. "Mexendo na Ferida": Os Erros de Enfermagem nos Média Brasileiros e Portugueses. Pensar Enferm [Internet]. 2016; [cited 2017 Jun 18]; 20(1):52-62. Available from: http:// pensarenfermagem.esel.pt/files/Artigo4_52_62.pdf

18. Gomes ATL, Silva MF, Morais SHM, Chiavone FBT, Medeiros SM Santos VEP. Erro humano e cultura de segurança à luz da teoria "queijo suíço": análise reflexiva. Rev Enferm UFPE On Line (Recife) [Internet]. 2016 Sep; [cited 2017 Jun 18]; 10(Supl. 4):3646-52. Available from: https://periodicos.ufpe.br/revistas/revistaenfermagem/article/ view/11139

19. Bogarin DF, Zanetti ACB, Brito MFP, Machado JP, Gabriel CS, Bernardes A. Segurança do paciente: conhecimento de alunos de graduação em enfermagem. Cogitare Enferm [Internet]. 2014 Jul/Sep; [cited 2017 Jun 18]; 19(3):491-7. Available from: http://revistas.ufpr.br/cogitare/article/ view/33308/23221

20. Costa MRT, Ferreira SCM. A atividade de limpeza e o controle de infecção: uma revisão integrativa. Nursing (São Paulo). 2016;19(221):1432-35. Available from: http://pesquisa.bvs.br/aps/resource/pt/bde-29607 
21. Gomes MF, Moraes VL. O programa de controle de infecção relacionada à assistência à saúde em meio ambiente hospitalar e o dever de fiscalização da Agência Nacional de Vigilância Sanitária. Rev Dir Sanit [Internet]. 2017;18(3):43-61. Available from: http://dx.doi.org/10.11606/ issn.2316-9044.v18i3p43-61

22. Siqueira CL, Ferreira KM, Souza TC, Feldman LB. Sentimentos experimentados por equipes de enfermagem acerca dos erros de medicação. Cogitare Enferm [Internet]. 2016; [cited 2017 Jun 17]; 21(no.esp):1-10. Available from: http://revistas. ufpr.br/cogitare/article/ download/45411/pdf

23. Ferreira RA, Pangaio AMWS, Bernardes RR, Lima SS. Segurança do paciente e os eventos adversos: erro profissional ou do sistema? Rev Rede Cuid Saúde [Internet]. 2014; [cited 2017 Jun 18]; 8(23):1-15. Available from: http://publicacoes.unigranrio.edu.br/index.php/rcs/ article/view/2033

24. Silva TN, Freire MEM, Vasconcelos MF, Silva Junior SV, Silva WJC, Araújo PS, et al. Deontological aspects of the nursing profession: understanding the code of ethics. Rev Bras Enferm [Internet]. 2018 Jan/Feb;71(1):3-10. DOI: http://dx.doi.org/10.1590/0034-7167-20160565
25. Cortez EA, Silva ICM, Carmo TG, Cardoso F, Marçal C, Grangeiro R. latrogenia no cuidado da enfermagem: implicações éticas e penais. Rev Pesq Cuid Fental On Line [Internet]. 2009 May/Aug; [cited 2017 Jun 18]; 1(1):74-84. Available from: http://www.seer.unirio.br/index.php/ cuidadofundamental/article/view/292

26. Colpo JC, Camargo VC, Mattos SA. A imagem corporal da enfermeira como objeto sexual na mídia: um assédio a profissão. Cogitare Enferm [Internet]. 2006 Jan/Apr; [cited 2017 Jun 17]; 11(1):67-72. Available from: http://revistas.ufpr.br/cogitare/article/download/5975/4275. DOI: http://dx.doi.org/10.5380/ce.v11i1.5975

27. Lage CEB, Alves MS. (Des)valorização da Enfermagem: implicações no cotidiano do Enfermeiro. Enferm Foco [Internet]. 2016; [cited 2017 Jun 17]; 7(3/4):12-6. Available from: http://revista.cofen.gov.br/index. php/enfermagem/article/view/908

28. Porto F, Neto M. Enfermeira na Imprensa llustrada Brasileira (18901925): assinatura imagética. Patrim Mem (São Paulo, Unesp) [Internet]. 2014; [cited 2017 Jun 17]; 10(1):199-221. Available from: http://pem. assis.unesp.br/index.php/pem/article/view/421/737

29. Vaghetti HH. As organizações da enfermagem e da saúde no contexto da idade média: o cuidado e a ciência no mundo e no Brasil. In: Padilha MI, Borenstein MS, Santos I, organizadores. Enfermagem: História de uma profissão. $2^{\mathrm{a}}$ ed. Florianópolis: Difusão Editora; 2015. p. 83-110.

a Article extracted from Master Thesis with the title "Press media and (re/de) construction of professional identity of Brazilian Nursing". Authorship by Amina Regina Silva, under Prof. Maria Itayra Coelho de Souza Padilha Supervisor. Nursing Graduate Program from Universidade Federal de Santa Catarina (UFSC). 2017. 